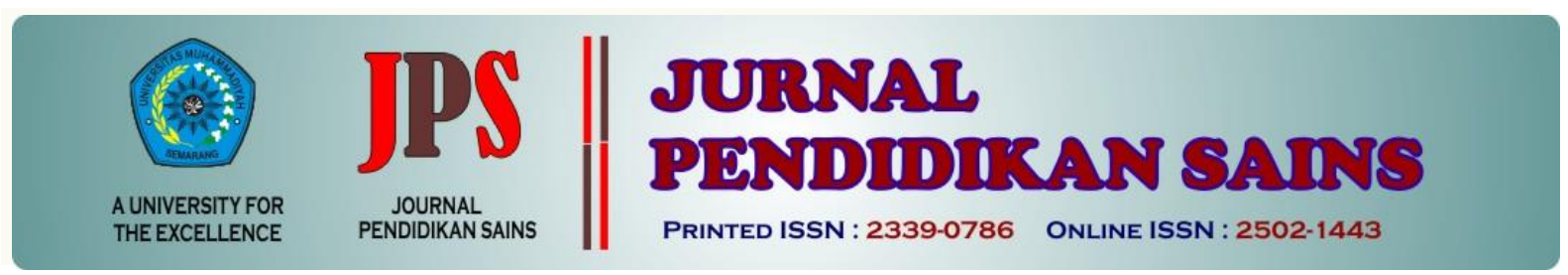

http://jurnal.unimus.ac.id/index.php/JPKIMIA

\title{
HUBUNGAN KETERAMPILAN GENERIK SAINS DAN SIKAP ILMIAH MELALUI MODEL INKUIRI DITINJAU DARI DOMAIN KOGNITIF
}

\author{
Oleh: \\ Meidini Martiningsih ${ }^{1}$, Risya Pramana Situmorang ${ }^{2}$, Susanti Pudji Hastuti ${ }^{3}$ \\ ${ }^{123}$ Program Studi Pendidikan Biologi, Fakultas Biologi, UKSW, Salatiga
}

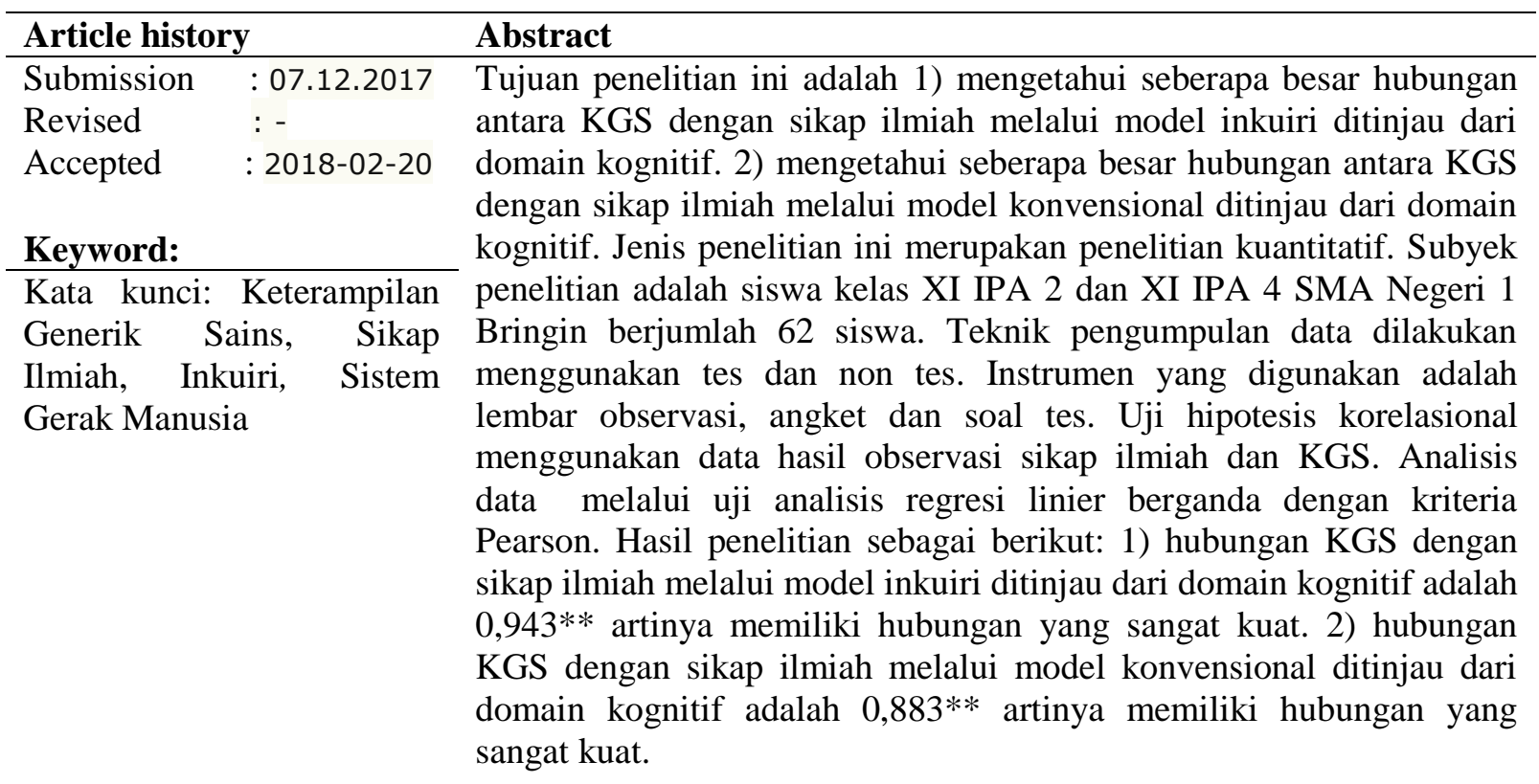

\section{Pendahuluan}

Biologi merupakan ilmu yang berkaitan dengan cara mencari tahu, memahami lingkungan dan mahkluk hidup secara sistematis. Maksudnya adalah biologi sebagai ilmu sains memberikan kesempatan pada siswa untuk menemukan sendiri fakta-fakta dan konsep-konsep biologi. Aksari (2012) menjelaskan bahwa proses yang dialami siswa dalam pembelajaran untuk mendapatkan pengetahuannya merupakan proses sains. Hal tersebut mampu diketahui melalui implementasi pembelajaran materi biologi yaitu pada materi sistem gerak manusia. Melalui pembelajaran tersebut siswa mampu menemukan sendiri fakta-fakta dan konsep-konsep mengenai penyusun dari rangka tubuh manusia. Oleh karena itu, proses dan kerja sains penting dalam membekali cara penyelidikan siswa. Memperhatikan struktur kedalaman materi sains, Chiapetta dan Koballa (2010) mengungkapkan bahwa Sains meliputi cara berpikir, penyelidikan dan interaksi dengan teknologi dan masyarakat.

Berdasarkan peran dan hakikat biologi sebagai sains maka proses belajar idealnya harus bertumpu pada proses ilmiah yang

*Corresponding Author:

Nama : Meidini Martiningsih

Lembaga : Pendidikan Biologi, Fakultas Biologi, UKSW

Email : meidini2505@gmail.com 
melibatkan berbagai keterampilan proses sains. Menurut Rahmawati, dkk (2016) terdapat dua keterampilan saintifik yaitu keterampilan dasar proses sains yang dimulai dari mengobservasi, mengklasifikasi, memperdiksi, mengukur, menyimpulkan dan mengkomunikasikan. Selanjutnya yaitu keterampilan proses sains yang meliputi: mengidentifikasi, mendefenisikan variabel, merumuskan hipotesis, merancang eksperimen, mengumpulkan dan mengolah data, menafsirkan data, membuat tabel dan grafik, menggambarkan hubungan anatra variabel dan menarik kesimpulan (Rahmawati, dkk , 2016). Keterampilan dasar dan proses sains merupakan upaya dalam memahami fenomena biologi sebagai sebuah proses penemuan.

Menurut Prabowo, dkk (2016) terdapat keterampilan yang melatih cara berpikir sekaligus keterampilan siswa dalam memecahkan permasalahan dalam sains yaitu Keterampilan Generik Sains (KGS). KGS melatih keterampilan berpikir logis, interaktif, kristis dan inovatif, yang disesuaikan dengan perkembangannya kemampuan pada siswa (Prabowo, dkk, 2016). KGS dikenal sebagai keterampilan dasar yang harus dimiliki dan perlu dikembangkan oleh setiap individu (Muspiroh, 2012). Brotosiswoyo dalam Agustianingsih (2014), menyebutkan bahwa KGS sains dikembangkan dalam 9 jenis keterampilan, meliputi pengamatan tentang gejala alam baik dilakukan secara langsung (direct observation) maupun pengamatan tidak langsung (indirect observation), kesadaran tentang skala besaran (sense of scale), bahasa simbolik (symbolic language), kerangka logika taat asas (logical self-consistency) dari hukum alam, inferensi logika, hukum sebab akibat (causality), pemodelan matematika (matemathical modelling), dan membangun konsep (concept formation).

Keterampilan Generik Sains (KGS) merupakan kemampuan berpikir dan bertindak berdasarkan pengetahuan yang dimiliki individu, setiap manusia memiliki keterampilan generik sains yang perlu dikembangkan seiring dengan berkembangnya otak manusia. Peningkatan keterampilan generik sains cocok mulai diterapkan pada siswa tingkat menengah atas yang tidak lagi dianggap seperti anak kecil dan sudah mampu mencari sendiri solusi jika dihadapkan dengan persoalan khususnya persoalan mengenai masalah belajar. Selain Itu, KGS juga dapat diartikan sebagai suatu keterampilan untuk melaksanakan atau melakukan suatu pekerjaan yang dilandasi oleh pengetahuan sendiri dan didukung oleh sikap kerja yang ditutuntut oleh pekerjaan tersebut. Keterampilan ini merupakan perpaduan antara pengetahuan dengan keterampilan yang bukan hanya meliputi keterampilan motorik saja melainkan juga fungsi mental yang bersifat kognitif.

Keterampilan ini memiliki peranan yang sangat penting dalam meningkatkan pemahaman siswa terhadap teori dan konsepkonsep biologi yang ada serta mendukung pembelajaran dengan memberikan penekanan pada proses dan produk sains (Fadlan, 2012). Keterampilan ini sebagai suatu strategi kognitif yang dapat berkaitan dengan tiga aspek yang meliputi aspek kognitif, afektif dan psikomotor. Selain itu keterampilan ini juga perlu dimiliki siswa sebagai kemampuan dasar yang harus dimiliki siswa yang bersifat umum, fleksibel dan berorientasi sebagai bekal mempelajari ilmu pengetahuan yang lebih tinggi. Sehingga dalam mempelajari biologi, siswa diharapkan dapat mudah dalam memahami konsep-konsep yang dianggap rumit dan bersifat abstrak apabila dalam pembelajaran disertai dengan contoh yang konkrit, hal tersebut yang melandasi perlunya diterapkanya keterampilan generik sains. Proses pembelajaran Biologi sebagai suatu fenomena sains diharapkan mampu mengajak siswa memecahkan masalah yang dihadapi dalam kehidupan sehari-hari dengan cara menemukan sendiri konsep-konsep sains yang telah dipelajari dan mampu mengambil keputusan dengan tepat melalui percobaan sehingga melatih keterampilan generik sains (Febriana, dkk, 2016).

Biologi meliputi produk dan proses yang tidak dapat dipisahkan. Pada aspek produk, siswa diharapkan mampu memahami konsep, teori dan hukum, sedangkan dilihat dari proses, siswa diharapkan mampu mempunyai keterampilan kerja ilmiah atau keterampilan proses. Pada pembelajaran dengan penerapan keterampilan proses melibatkan berbagai keterampilan kognitif (menggunakan pikiranya sendiri), manual (dalam penggunaan alat dan bahan), sosial (berinteraksi dengan sesamanya) dalam proses pembelajaran (Rustaman, 2005).

Sikap ilmiah merupakan gambaran mengenai bagaimana seharusnya siswa bersikap dalam belajar, menanggapi suatu permasalahan, malaksanakan tugas, dan mengembangkan diri yang pada akhirnya akan mempengaruhi hasil belajar siswa kearah yang positif. Sikap ilmiah itu sendiri antara lain sikap jujur, teliti, 
tanggungjawab, disiplin, dan rasa ingin tahu. Yuliani dalam Putra (2010) menyebutkan kalau sikap ilmiah berperan penting dalam menumbuhkan keinginan dan semangat siswa dalam belajar. Sejalan dengan itu, Slameto (2003) menegaskan bahwa sikap juga dapat menentukan hasil belajar siswa. Sikap dipandang mampu menentukan apa yang dicari siswa dalam kehidupanya melalui interaksi dengan sesamanya. Sehingga dapat disimpulkan bahwa tingkat sikap ilmiah yang dimiliki oleh siswa memiliki peranan terhadap perkembangan hasil belajar.

Pembelajaran biologi di sekolah hendaknya menekankan pada pemberian pengalaman belajar kepada siswa untuk dapat mengembangkan kompetensi siswa melalui penggunaan dan pengembangan keterampilan generik sains dan sikap ilmiah siswa. KGS sebagai metode ilmiah dalam hal mempelajari sains juga harus diimbangi atau diiringi dengan adanya sikap yaitu sikap ilmiah. Sikap ilmiah merupakan sikap yang diperlihatkan oleh para ilmuan ketika melakukan suatu proses dalam hal menemukan pengetahuannya atau melakukan kegiatan keilmuanya (Karyodiputro, 2015). Proses pembelajaran sains, dalam hal menemukan pengetahuan dan konsep siswa dituntut untuk mengembangkan KGS melalui pengembangan sikap ilmiah yang berkaitan dengan cara bagaimana siswa tersebut bersikap ketika melakukan proses dalam hal mendapatkan ilmu pengetahuanya.

Keterampilan Generik Sains (KGS) dan sikap ilmiah dipengaruhi oleh kondisi internal siswa. Salah satu faktor internal siswa yaitu kemampuan kognitif siswa, siswa yang memiliki kondisi akademik rendah akan lambat dalam menangkap dan memahami materi pelajaran yang disampaikan di sekolah, sehingga dibutuhkan waktu yang relatif lama dibandingkan dengan siswa lainya. Hasil wawancara dengan guru Biologi SMA Negeri 1 Bringin pada bulan Agustus 2017, tingkat kemampuan kognitif siswa tinggi dan rendah mengalami perbedaan yang cukup signifikan dari hasil akademiknya. Kemampuan kognitif yang berbeda di sekolah tersebut kurang mendapatkan perhatian yang khusus oleh guru, siswa yang memiliki kemampuan kognitif rendah akan selalu berada dalam kondisi yang sama begitu juga dengan siswa yang memiliki kemampuan kognitif tinggi.

Perbedaan kemampuan kognitif siswa buktinya jarang terfasilitasi oleh guru. Apalagi proses pembelajaran yang lebih berorientasi pada metode ceramah yang dianggap kurang relevan terhadap pengembangan KGS dan sikap ilmiah. Dampaknya, siswa menjadi tidak maksimal dan hasil belajar menjadi rendah.Keterampilan Generik Sains dan sikap ilmiah perlu dibangun dengan melakukan pembelajaran yang aktif dan inovatif. Suriyani dalam Darmawan dkk (2013) menyatakan bahwa KGS bertumpu pada pembelajaran yang berpusat pada siswa (student centered). Suriyani membuktikan bahwa inkuiri dapat memberdayakan keterampilan generik sains siswa. Sejalan dengan Darmawan, dkk (2013), bahwa model inkuiri dapat meningkatkan pemahaman konsep dan keterampilan generik sains siswa SMA. Berdasarkan beberapa penelitian yang sudah dilakukan, dapat dikatakan bahwa pembelajaran yang berpusat pada siswa, pasti mengarah kepada proses inkuiri untuk membangun pengetahuan siswa.

Berdasarkan analisis dan kajian penelitian yang dilakukan, proses untuk memfasilitasi kemampuan siswa dalam tingkatan kognitif yang berbeda dianggap penting melalui implementasi model inkuiri. Model inkuiri merupakan perluasan dari model discovery yang digunakan lebih mendalam, melalui model ini siswa mengalami serangkaian pembelajaran yang melibatkan secara maksimal seluruh kemampuan siswa untuk mencari dan menyelidiki secara sistematis, kritis, logis, analitis, sehingga mereka dapat merumuskan sendiri penemuanya dengan rasa percaya diri yang tinggi (Al-Tabany, 2014).

Penelitian yang sudah dilakukan oleh Yuaniarita (2014) membuktikan bahwa inkuiri terbimbing mampu meningkatkan keterampilan generik sains siswa SMP menunjukan bahwa secara kualitas proses pembelajaran juga dapat membangun suasana pembelajaran menjadi lebih menarik dengan adanya kerjasama dan interaksi antar siswa. Selain itu, setiap siswa dalam kelompok dapat memadukan berbagai ide dan dapat berpendapat, saling berdiskusi dan beragumentasi dalam memahami suatu pokok bahasan serta memecahkan suatu permasalahn yang dihadapi dalam kelompoknya. Berdasarkan latar masalah tersebut, maka perlu dilakukan penelitian tentang "Hubungan Keterampilan Generik Sains dan Sikap Ilmiah melalui Model Inkuiri ditinjau dari Domain Kognitif".

\section{Metode Penelitian}

Jenis Penelitian 
Jenis penelitian ini adalah penelitian kuantitatif dengan metode deskriptif kuantitatif melalui analisis korelasional.

Waktu dan Tempat Penelitian

Penelitian ini akan dilaksanakan di SMA Negeri 1 Bringin yang beralamat di jalan Wibisono Gang II, Nomor 03 Bringin, Jawa Tengah. Pelaksanaan penelitian dilaksanakan pada bulan September sampai November 2017 atau semester 1 tahun ajaran 2017/2018.

Target/Subjek Penelitian

Subjek penelitian dalam penelitian ini adalah siswa kelas XI IPA 2 SMA Negeri 1 Bringin yang berjumlah 30 orang, dengan jumlah siswa laki-laki 9 orang dan siswa perempuan 21 orang sebagai kelas eksperimen dan kelas XI IPA 4 sebagai kelas kontrol dengan jumlah siswa 32 orang, terdiri dari siswa laki-laki 6 orang dan siswa perempuan 26 orang. Teknik pengambilan sampel menggunakan purposive sampling.

Teknik Pengumpulan Data

Perolehan data atau informasi yang representatif pada penelitian ini, maka penelitian menggunakan 3 teknik pengumpulan data yaitu observasi. Lembar observasi digunakan untuk melakukan observasi mengenai pembelajaran yang dilakukan siswa maupun guru baik sebelum dilakukanya penelitian maupun saat dilakukanya penelitian dengan menggunakan model pembelajaran inkuiri untuk mengetahui tingkat keterampilan generik sains yang dimiliki oleh siswa SMA Negeri 1 Bringin. Selain itu, lembar observasi juga digunakan untuk mengetahui sikap ilmiah siswa.

Angket digunakan untuk mengetahui sikap ilmiah siswa. Angket diberikan kepada siswa baik sebelum dilakukanya penelitian maupun sesudah dilakukanya penelitian.

Tes tertulis dilakukan untuk mengetahui tingkat pengetahuan siswa atau penguasaan materi pembelajaran.

Teknik Analisis Data

Teknik analisis data menggunakan teknik analisis kuantitatif untuk observasi sikap ilmiah dan keterampilan generik sains. Analisis data penelitian terdiri atas uji validitas dan uji reliabilitastes dan nontes. Analisis data diperoleh dengan pengujian analisis regresi linier berganda menggunakan SPSS 16.0. Uji prasyarat hipotesis akan dilakukan uji normalitas dan homogenitas.

\section{Hasil Penelitian dan Pembahasan}

1.1 Hubungan antara Keterampilan Generik Sains (KGS) dengan Sikap Ilmiah melalui Model Inkuiri Ditinjau dari Domain Kognitif

Hasil analisis untuk keseluruhan lembar observasi baik untuk KGS maupun sikap ilmiah kemudian diolah dengan menggunakan SPSS melalui uji korelasi Pearson untuk membuktikan ada tidaknya hubungan antar variabel yang diteliti, data tersebut tersaji pada Tabel 1 berikut ini.

Tabel 1. Hasil Uji Korelasi Pearson Antara Keterampilan Generik Sains (KGS), Sikap Ilmiah dan Kognitif Siswa Melalui Model Inkuiri.

\begin{tabular}{ccccc}
\hline & & KGS & $\begin{array}{c}\text { Sikap } \\
\text { Ilmiah }\end{array}$ & Kognitif \\
\hline KGS & $\begin{array}{l}\text { Korelasi } \\
\text { Pearson }\end{array}$ & 1 & $.943^{* *}$ & -.236 \\
\hline Sikap & $\begin{array}{c}\text { Korelasi } \\
\text { Ilmiah }\end{array}$ & $.943^{* *}$ & 1 & -.322 \\
\hline Pearson & & & \\
\hline Kognitif & $\begin{array}{c}\text { Korelasi } \\
\text { Pearson }\end{array}$ & -.236 & -.322 & 1 \\
\hline
\end{tabular}

Tabel 1 diatas menunjukan bahwa antara KGS dengan sikap ilmiah menunjukan nilai koefesien korelasi $0.943^{* *}$, nilai ini menurut kriteria korelasi Sugiyono (2010) memiliki arti terdapat korelasi yang sangat kuat yang artinya antara KGS dengan sikap ilmiah pada siswa kelas XI IPA 2 SMA Negeri 1 Bringin memiliki hubungan yang sangat kuat. Hal ini dapat diartikan bahwa siswa yang diajarkan dengan menggunakan model inkuiri memiliki hubungan yang sangat kuat korelasinya dengan KGS dan sikap ilmiah, yakni siswa yang memiliki tingkat KGS yang tinggi juga akan memiliki tingkat sikap ilmiah yang tinggi juga, begitu juga sebaliknya. Hasil ini dikarenakan, siswa kelas eksperimen melakukan kegiatan praktikum untuk mengidentifikasi struktur tulang dan pembentukan tulang. Siswa diposisikan sebagai peneliti untuk menemukan permasalahan tentang alat gerak manusia. Dalam kegiatannya siswa distimulus untuk berkreasi dalam melakukan aktivitas praktikum. Secara tidak langsung aktivitas siswa yang muncul dalam praktikum merupakan keterampilanketerampilan dan sikap yang dapat diukur, dalam konteks ini adalah keterampilan generik sains dan sikap ilmiah.

Hal ini juga sejalan dengan penelitian yang sudah dilakukan oleh Trihastuti (2008) yang berpendapat bahwa keterampilan proses 
sains yang dielaborasikan dalam pembelajaran sains dapat melibatkan berbagai keterampilan baik yang bersifat intelektual, manual maupun sosial. Dengan terbentuknya produk pengetahuan melalui proses kerja ilmiah ini, maka akan terbentuklah sikap-sikap ilmiah.

Hubungan antara KGS dan sikap ilmiah dengan kognitif, dari hasil data di atas menunjukan nilai korelasi antara kognitif dengan KGS -0,236 dan antara kognitif dengan sikap ilmiah menunjukan nilai koefesien korelasi $-0,322$. Kedua nilai koefesien korelasi tersebut menurut kriteria Sugiyono (2010) menunjukan tidak adanya hubungan antara kedua variabel tersebut yang artinya baik antara kognitif dengan KGS maupun antara kognitif dengan sikap ilmiah tidak ada hubungan yang signifikan. Sehingga dapat diartikan bahwa penggunaan model inkuiri pada kelas eksperimen belum tentu mampu meningkatkan KGS dan sikap ilmiah siswa sejalan dengan tingkat kognitif siswa. Selain itu, tidak adanya korelasi antara sikap ilmiah dengan kognitif maupun antara KGS dengan kognitif disebabkan oleh beberapa faktor dalam pembelajaran. Diantaranya adalah pelaksanaan model inkuiri yang dapat memfasilitasi siswa dalam KGS dan sikap ilmiah. Sementara untuk hasil belajar kognitif siswa masih dipengaruhi oleh domain kognitif siswa dari kategori tinggi sampai rendah.

Hasil analisis nilai kognitif siswa menunjukan bahwa terdapat $27 \%$ siswa yang memiliki kemampuan kognitif yang rendah, memiliki KGS yang masuk dalam kriteria baik, dan sikap ilmiah yang masuk dalam kriteria baik. Terdapat $56 \%$ siswa memiliki kemampuan kognitif sedang, memiliki KGS yang masuk dalam kriteria baik dan memiliki sikap ilmiah dengan kriteria baik, sedangkan untuk siswa yang memiliki kemampuan kognitif yang tinggi sebesar $17 \%$, memiliki KGS yang masuk dalam kriteria tidak baik 40 $\%$ dan sikap imiah termasuk dalam kriteria tidak baik. Hubungan antara variabel KGS dan sikap ilmiah melalui model inkuiri yang ditinjau dari domain kognitif disajikan pada Tabel 2 sebagai berikut.

Tabel 2. Uji Anova Hubungan Keterampilan Generik Sains (KGS) dan Sikap Ilmiah Melalui Model Inkuiri Ditinjau dari Domain Kognitif Siswa.

\begin{tabular}{lllcll}
\hline Model & $\begin{array}{l}\text { Sum of } \\
\text { Square }\end{array}$ & df & $\begin{array}{c}\text { Mean } \\
\text { Square }\end{array}$ & F & Sig \\
\hline
\end{tabular}

\begin{tabular}{llllll}
\hline Regression & 420.318 & 2 & 210.159 & 1.394 & $.265^{\mathrm{a}}$ \\
\hline
\end{tabular}

Tabel 2 diatas merupakan hasil uji SPSS Anova mengenai hubungan antara KGS dan sikap ilmiah melalui model inkuiri yang ditinjau dari domain kognitif siswa. Dari hasil analisis diperoleh nilai signifikansi sebesar 0,265 . Jika dibandingkan dengan $\alpha$ ( Sig. $>\alpha$ ), yaitu $0,265>0,05$ sehingga $\mathrm{H}_{0}$ diterima. Artinya, pada kelas eksperimen yang diajarkan dengan menggunakan model inkuiri tidak ada korelasi atau hubungan antara KGS dan sikap ilmiah terhadap kognitif siswa. Siswa yang memiliki KGS yang tinggi dan rendah serta siswa yang memiliki sikap imiah yang tinggi dan rendah tidak menunjukan perbedaan hasil terhadap pemahaman konsep siswa atau kognitif siswa. Siswa yang memiliki tingkat kognitif yang tinggi, belum tentu memiliki tingkat keterampilan generik sains dan sikap ilmiah yang tinggi juga ataupun sebaliknya, dikarenakan beberapa siswa kurang terampil dalam melaksanakan kegiatan eksperimen yaitu melalui praktikum yang dilaksanakan dikelas sehingga beberapa siswa memiliki tingkat KGS dan sikap ilmiah yang rendah namun memiliki pemahaman konsep yang baik. Sebagaimana hasil penelitian yang telah dilakukan oleh Yuliani (2012) yang menyatakan bahwa meskipun siswa kurang terampil dalam melakukan aktivitas proses sains belum tentu siswa tersebut memiliki tingkat kognitif yang rendah, dikarenakan pemahaman konsep siswa dapat didapatkan siswa dengan cara membaca dan mengerjakan soal latihan diluar proses pembelajaran. Selain itu, tingkat kognitif siswa yang rendah memang tidak bisa terpengaruh menjadi tinggi oleh adanya pembelajaran menggunakan model inkuiri.

\subsection{Hubungan Antara Keterampilan Generik} Sains (KGS) dengan Sikap Ilmiah melalui Model Konvensional Ditinjau dari Domain Kognitif.

Seperti halnya pada kelas eksperimen, lembar observasi mengenai KGS dan sikap ilmiah yang diberikan pada kelas kontrol kemudian dianalisis dengan menggunakan uji SPSS melalui uji korelasi Pearson untuk membuktikan ada tidaknya hubungan antar variabel yang diteliti, data tersebut tersaji pada Tabel 3 berikut ini.

Tabel 3. Hasil Uji Korelasi Pearson Antara Keterampilan Generik Sains (KGS), 
Sikap Ilmiah dan Kognitif Siswa Melalui Model Konvensional.

\begin{tabular}{llccc}
\hline & & KGS & $\begin{array}{c}\text { Sikap } \\
\text { Ilmiah }\end{array}$ & Kognitif \\
\hline (KGS) & $\begin{array}{l}\text { Korelasi } \\
\text { Pearson }\end{array}$ & 1 & $.883^{* *}$ & $.561^{* *}$ \\
\hline Sikap & $\begin{array}{l}\text { Korelasi } \\
\text { Ilmiah }\end{array}$ & $.883^{* * *}$ & 1 & $.557^{* *}$ \\
\hline Kogarson & & $.557^{* *}$ & 1 \\
& $\begin{array}{l}\text { Korelasi } \\
\text { Pearson }\end{array}$ & $.561^{* *}$ & .55 . & \\
\hline
\end{tabular}

Berdasarkan dari hasil analisis Tabel 3 diatas menunjukan bahwa antara KGS dengan sikap ilmiah memiliki nilai koefesien korelasi sebesar $0,883^{* *}$ menurut kriteria korelasi Sugiyono (2010) nilai tersebut termasuk kedalam kriteria korelasi yang sangat kuat. Adanya hubungan tersebut dapat terlihat saat siswa pada kelas kontrol ingin mempelajari suatu konsep tertentu pada proses pembelajaran siswa melakukan diskusi mengenai suatu permasalahan, indikator KGS juga dapat muncul misalnya saat siswa berdiskusi dalam memecahkan masalah berdasarkan rujukan. Sehingga sikap ilmiah siswa juga akan muncul seperti berkopromi atau bermusyawarah untuk mendapatkan keputusan secara berkelompok.

Hubungan antara KGS dengan kognitif menunjukan nilai koefesien korelasi sebesar 0,561 yang menunjukan adanya korelasi sedang. Siswa yang memiliki tingkat KGS yang baik seperti pada aspek inferensi logika dalam hal memecahkan masalah berdasarkan rujukan juga akan membantu siswa dalam memahami konsep. Sedangkan hubungan antara sikap ilmiah dengan kognitif siswa memiliki nilai koefesien korelasi sebesar $0,557^{* *}$ dan termasuk ke dalam kriteria korelasi sedang. Siswa yang memiliki tingkat sikap ilmiah yang tinggi cenderung memiliki tingkat motivasi dalam belajar yang tinggi, sehingga dengan adanya motivasi yang tinggi siswa dalam hal belajar maka akan menghasilkan kemampuan kognitif siswa yang tinggi pula. Sejalan dengan penelitian oleh Vello, dkk. (2013) yang berpendapat bahwa sikap ilmiah memiliki pengaruh yang positif terhadap pemahaman konsep siswa karena sikap ilmiah yang dimiliki siswa mendorong mereka untuk lebih tertarik dan terlibat dalam pembelajaran IPA sehingga pemahaman konsep siswa juga menjadi lebih baik.

Sementara siswa yang memiliki sikap ilmiah yang rendah cenderung tidak antusias dalam mengikuti pembelajaran yang berdampak pada pemahaman konsep siswa yang rendah karena siswa sulit dalam memahami konsep. Hasil belajar kognitif pada kelas kontrol dengan pembelajaran yang menggunakan model konvensional tidak memiliki hubungan yang signifikan dengan domain siswa yang berbeda dari tingkat tinggi sampai rendah. Berdasarkan dari hasil analisis menunjukan bahwa siswa dengan kemampuan kognitif yang rendah sebesar $25 \%$ memiliki KGS dengan kriteria tidak baik dan memiliki sikap ilmiah dengan kriteria tidak baik, siswa dengan kemampuan kognitif yang sedang sebesar $59 \%$ memiliki KGS dengan kriteria baik dan sikap ilmiah dengan kriteria baik. Sedangkan siswa dengan kemampuan kognitif tinggi sebesar $16 \%$ memiliki KGS dengan kriteria baik dan sikap ilmiah yang baik .Untuk mengetahui hubungan ketiga variabel yaitu KGS dan sikap ilmiah melalui model konvensional yang ditinjau dari domain kognitif siswa tersaji pada Tabel 4 sebagai berikut.

Tabel 4.Uji Anova Hubungan Keterampilan Generik Sains (KGS) dan Sikap Ilmiah Melalui Model Konvensional Ditinjau dari Domain Kognitif Siswa.

\begin{tabular}{cccccc}
\hline Model & $\begin{array}{c}\text { Sum of } \\
\text { Square }\end{array}$ & df & $\begin{array}{c}\text { Mean } \\
\text { Square }\end{array}$ & F & Sig \\
\hline Regression & 11.723 & 2 & 5.862 & 7.641 & $\mathbf{. 0 0 2}^{\mathbf{a}}$ \\
\hline
\end{tabular}

Berdasarkan dari Tabel 4 diatas menunjukan bahwa hubungan dari ketiga variabel yaitu KGS dan sikap ilmiah yang ditinjau dari domain kognitif siswa melalui model konvensional pada kelas XI IPA 4 SMA Negeri 1 Bringin melalui uji Anova menunjukan nilai signifikansi sebesar $0,002^{\mathrm{a}}$. Jika dibandingkan dengan $\alpha$ ( Sig. $<\alpha$ ), yaitu $0,002<0,05$ sehingga $\mathrm{H}_{\mathrm{a}}$ diterima. Artinya, bahwa terdapat korelasi atau hubungan yang signifikan antara KGS, sikap ilmiah melalui implementasi model konvensional yang ditinjau dari domain kognitif. Model konvensional yang diterapkan di kelas kontrol memungkinkan siswa yang memiliki tingkat KGS dan sikap ilmiah yang tinggi juga akan memiliki kemampuan kognitif yang tinggi juga, begitu juga sebaliknya. Penggunaan model konvensional kurang mampu memfasilitasi kemampuan siswa baik dari KGS, sikap ilmiah dan kognitif yang berbeda-beda. Sehingga, siswa yang memiliki KGS dan sikap ilmiah yang rendah juga akan berdampak pada kemampuan kognitif yang rendah juga. 
Hasil analisis lembar observasi mengenai aspek KGS menunjukan perbandingan ketercapaian aspek KGS pada kelas eksperimen dan kelas kontrol bahwa dari lima aspek KGS yang diteliti, terdapat tiga aspek yang menunjukan pencapaian yang lebih tinggi pada kelas eskperimen dibandingkan dengan kelas kontrol yakni pengamatan langsung, hukum sebab akibat dan membangun konsep. Sedangkan dua aspek lainya yakni pemodelan dan inferensi logika menunjukan pencapaian yang lebih tinggi pada kelas kontrol dari pada kelas eksperimen. Kelas eksperimen yang dilaksanakan pembelajaran dengan menggunakan model inkuiri memungkinkan siswa melakukan pembelajaran dengan metode ilmiah untuk membuktikan hipotesis dalam sebuah percobaan. Sementara, model konvensional kurang memfasilitasi siswa dalam mengidentifikasi suatu peristiwa atau fenomena sehingga pada kelas kontrol aspek hukum sebab akibat memiliki rerata yang lebih rendah. Hal ini juga tidak terlepas dari esensi model inkuiri yang menyatakan bahwa model inkuiri merupakan model yang menekankan pada aktivitas siswa secara maksimal dalam mencari dan menemukan sehingga siswa dijadikan sebagai subyek dalam penelitian ini (AlTabany, 2014).

Aspek pemodelan pada kelas eksperimen memiliki rerata yang paling rendah, dikarenakan keterbatasan siswa dalam menyajikan hasil sesuai dengan materi yang dipelajari. Inferensi logika pada kelas kontrol memiliki rerata yang paling tinggi dibandingkan dengan aspek lainya dikarenakan siswa kelas XI IPA 4 lebih aktif dalam mencari rujukan dalam memecahkan masalah. Secara umum, kriteria pencapaian KGS siswa pada kelas eksperimen menunjukan ragam kriteria sangat baik 1 siswa, baik 19 siswa, cukup 6 siswa dan tidak baik 4 siswa. Sedangkan pada kelas kontrol kriteria sangat baik terdapat 4 siswa, baik 17 siswa, cukup 5 siswa dan tidak baik 6 siswa.

Hasil analisis lembar observasi mengenai sikap ilmiah menggunakan empat aspek yang diteliti yakni rasa ingin tahu, kejujuran, berpikir kritis dan kerjasama. Berdasarkan dari hasil analisis menunjukan bahwa dari empat aspek yang diteliti terdapat dua aspek yakni kejujuran dan kerjasama yang memiliki pencapaian yang lebih tinggi pada kelas eksperimen dari pada kelas kontrol. Hasil ini dikarenakan pada kelas eksperimen saat melakukan kegiatan praktikum, secara tidak langsung siswa bekerjasama secara berkelompok dalam menyelesaikan tugas kemudian menyampaikan fakta sesuai dengan apa yang ditemukan. Sedangkan dua aspek terakhir yakni rasa ingin tahu dan berpikir kritis memiliki pencapaian yang lebih tinggi pada kelas kontrol dibandingkan dengan kelas eksperimen. Pencapaian kriteria sikap ilmiah siswa menunjukan bahwa pada kelas eskperimen yang termasuk dalam kriteria sangat baik 1 siswa, baik 24 siswa, cukup 0 siswa dan tidak baik 5 siswa. Kelas kontrol, siswa yang termasuk dalam kriteria sangat baik 2 siswa, baik 20 siswa, cukup 6 siswa dan tidak baik 4 siswa.

Hasil analisis angket sikap ilmiah siswa yang diberikan pada akhir pertemuan baik pada kelas eksperimen dan kelas kontrol tersaji pada Gambar 1 sebagai berikut.

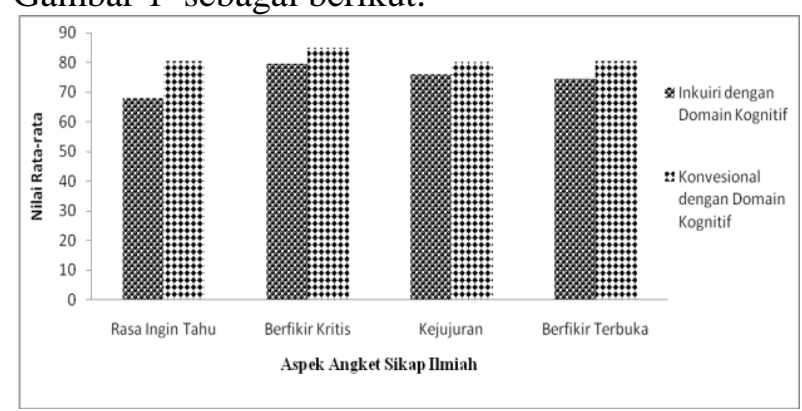

Gambar 1. Perbandingan Sikap Ilmiah Siswa Kelas Eksperimen (XI IPA 2) dan Kelas Kontrol (XI IPA 4)

Berdasarkan dari Gambar 1 di atas menunjukkan bahwa respon siswa terhadap sikap ilmiah pada kelas eksperimen melalui model inkuiri dan kelas kontrol melalui model konvensional, menunjukkan bahwa indikator rasa ingin tahu, berpikir kritis, kejujuran dan berpikir terbuka memiliki rerata yang tinggi pada kelas kontrol dibandingkan dengan kelas eksperimen. Sedangkan berdasarkan dari hasil analisis kriteria respon sikap ilmiah siswa menyatakan bahwa pada kelas eskperimen siswa dengan respon sangat sejutu sebanyak 5 siswa, setuju 8 siswa, tidak setuju 12 siswa dan sangat tidak setuju 5 siswa. Sementara pada kelas kontrol siswa yang menunjukan respon sangat setuju 5 siswa, setuju 16 siswa, tidak setuju 6 siswa dan sangat tidak setuju 5 siswa.

Siswa kelas eksperimen maupun siswa kelas kontrol menunjukan hasil analisis yang berbeda antara lembar observasi sikap ilmiah dengan hasil angket sikap ilmiah, artinya respon siswa terhadap pembelajaran dengan yang dilakukan siswa saat berlangsungnya pembelajaran menunjukan hasil yang berbeda. Hasil ini dapat dipengaruhi oleh faktor model 
pembelajaran yang digunakan, seperti pada kelas kontrol yang menggunakan model konvensional yang kurang mampu memfasilitasi sikap ilmiah siswa sehingga respon siswa terhadap pembelajaran tidak sesuai dengan sikap siswa yang muncul saat berlangsungnya pembelajaran.

Secara umum, berdasarkan dari hasil nilai post test menunjukan nilai rata-rata nilai kognitif siswa kelas eksperimen yang diajarkan dengan model inkuiri memiliki nilai rata-rata yang lebih tinggi yaitu 62,73 dibandingkan dengan kelas kontrol yang diajarkan dengan model konvensional memiliki rata-rata 58,65 Sejalan dengan penelitian yang dilakukan oleh Hamdu (2007) yang menyatakan bahwa penerapan model inkuiri mampu meningkatkan pemahaman konsep siswa secara umum.

Penerapan pembelajaran yang berlansung di selama 1 bulan di SMA Negeri 1 Bringin diperoleh bahwa tidak adanya korelasi atau hubungan antara KGS dan sikap ilmiah yang ditinjau dari domain kognitif siswa. Hal ini dapat diartikan bahwa pembelajaran yang seharusnya dilakukan di SMA Negeri 1 Bringin dapat berorientasi kepada aktivitas siswa seperti penggunaan model inkuiri yang mampu memfasilitasi kemampuan siswa yang berbedabeda baik dari KGS, sikap ilmiah dan domain kognitif siswa yang berbeda-beda. Sehingga, melalui model inkuiri, siswa dengan kemampuan kognititf yang berbeda-beda mampu terfasilitasi dengan baik untuk pencapaian KGS dan sikap ilmiah siswa dalam hal pencapaian kemampuan kognitif siswa. Selain itu, penggunaan model inkuiri ini juga mampu meningkatkan hasil belajar kognitif dibandingkan dengan siswa yang diajarkan dengan model konvensional. Sedangkan penggunaan model konvensional yang diajarkan berdasarkan dari hasil uji statistik menunjukan adanya hubungan antara KGS dan sikap ilmiah yang ditinjau dari domain kognitif siswa. Artinya, penggunaan model konvensional kurang mampu memfasilitasi siswa yang memiliki kemampuan kognitif siswa yang berbeda-beda begitu juga dengan pencapaian KGS dan sikap ilmiah siswa. Hal ini juga akan berimbas pada pencapaian nilai kognitif siswa. Akan tetapi baik penggunaan model inkuiri maupun penggunaan model konvensional mampu memberikan hubungan yang kuat antara KGS dengan sikap ilmiah, sementara kemampuan kognitif siswa untuk model inkuiri lebih baik dalam memfasilitasi kemampuan kognitif siswa yang berbeda-beda.

\section{Simpulan dan Saran}

Simpulan

1.Hubungan Keterampilan Generik Sains (KGS) dengan sikap ilmiah melalui model inkuiri ditinjau dari domain kognitif adalah $0,943 * *$ artinya memiliki hubungan yang sangat kuat.

2.Hubungan Keterampilan Generik Sains (KGS) dengan sikap ilmiah melalui model konvensional ditinjau dari domain kognitif adalah $0,883^{* *}$ artinya memiliki hubungan yang sangat kuat

Saran

1.Guru perlu melakukan penilaian secara holistik kepada siswa, dikarenakan pada penelitian ini tidak ditemukan hubungan antara kognitif siswa dengan Keterampilan Generik Sains (KGS) dan sikap ilmiah siswa.

2.Guru perlu memperhatikan pemerdayaan aktivitas siswa didalam pembelajaran dengan penggunaan model inkuiri yang dapat menstimulus keterampilan dan sikap siswa.

\section{Daftar Pustaka}

Aksari, Y. D. (2012). Peningkatan Keterampilan Proses Sains dan Hasil Belajar Siswa Melalui Penerapan Strategi Pembelajaran Guide Inkuiri di SMP Negeri 26 Surakarta Kelas VIIB tahun Pelajaran 2011/2012. Skripsi, FKIP Universitas Sebelas Maret Surakarta.

Al-Tabany, T.I.B. (2014). Mendesain Model Pembelajaran Inovatif, Progresif, dan Kontekstual. Jakarta: Prenamedia Group. hal 86-87.

Astuti, E.K. (2014).Analisis Korelasi Antara Sikap Ilmiah dan Prestasi Belajar Siswa Kelas VII, SMP 4 Bengkulu pada Pembelajaran IPA Biologi dengan Model Siklus Belajar 5E. Skripsi, FKIP Universitas Bengkulu.

Brotosiwoyo, B.S. (2001). Hakikat Pembelajaran MIPA dan Kiat Pembelajaran Fisika di Perguruan Tinggi. Dalam Agustianingsih, W., Sarwanto, \& Suparmi. (2014). Pengembangan Instruksi Praktikum Berbasis Keterampilan Generik Sains pada Pembelajaran Fisika Materi Teori Kinetik 
Gas Kelas XI IPA SMA Negeri 8 Surakarta Tahun Ajaran 2012/2013. Jurnal Inkuiri. Vol. 1, hal 50-61.

Chiappetta, E.L., and T. R, Jr. Koballa. (2010).Science Instruction in the Middle and Secondary Schools Developing Fundamental Knowledge and Skills. 7th edition. Pearson. USA.

Darmawan, J., Halim, A., \& Nur, A. (2013).Metode Pembelajaran Eksperimen Berbasis Inkuiri untuk Meningkatkan Pemahaman Konsep dan Keterampilan Generik Sains Siswa SMA. Jurnal Pendidikan Sains Indonesia (JPSI).

Fadlan, A. (2012). Strategi Pengembangan Science Generic Skills (SGC) Calon Guru Fisika melalui Model Pembelajaran Group Investigation pada Mata Kuliah Praktikum. Jurnal Phenomenon, Volume 1 Nomor 1.

Febriana, A., Ibrohim, \& Mahanal, S. (2016). Potensi Pembelajaran Inkuiri dalam Menumbuhkan Sikap Siswa Terhadap Lingkungan.Prosiding Seminar Nasional Pendidikan IPA Pascasarjana UM, Vol 1 .

Hamdu. (2007). Pembelajaran Hidrolisis Garam Dengan Model Inkuiri untuk Mengembangkan Kemampuan Dasar Bekerja Ilmiah Siswa Kelas XI. Bandung: Sekolah Pasca Sarjana UPI.

Karyodiputro, M.I. (2015). Ekstrakulikuler Sains Sebagai Upaya Pengembangan Sikap Ilmiah dan Ketrampilan Proses Sains Peserta Didik di SDIT BINA Anak Islam Krapyak. Tesis, Program Studi Pendidikan Guru Madrasah Ibtidaiyah UIN Sunan Kalijaga.

Lestari, I. (2014). Sikap Ilmiah Siswa Kelas XI IPA 1 SMAN3 Bengkulu Tengah pada Pembelajaran Biologi Berpendekatan Inkuiri. Skripsi, FKIP Universitas Bengkulu.

Muspiroh, N. (2012). Analisis Kemampuan Generik Sains Mahasiswa Calon Guru Biologi pada Praktikum Anatomi Tumbuhan. Jurnal Scientiae Educatia, Vol.1, Edisi 1.
Prabowo, L.B., Ngazizah N., \& Sriyono. (2016). Analisis Keterampilan Generik Sains Siswa SMA Negeri Kelas X Sekabupaten Purworejo dalam Pembelajaran Fisika Tahun Pelajaran 2015/016. Jurnal Radiasi, Vol. 08, No. 1

Priyambodo, P., \& Sitomorang, R.P. (2017). Antigen dan Antibodi Pembelajaran. Yogyakarta: Pustaka Pelajar.hal. 223224.

Rahmawati, Koes H.S,. \& Dasna, I.W. (2016). Kajian Pengaruh Learning Cycle 5E Terhadap Keterampilan Proses Sains Peserta Didik SMP. Prosiding Seminar Nasional Pendidikan IPA Pascasarjana UM, Vol.1.

Roihah, I. (2009). Implikasi Teori Kognitif Jean Piaget dalam Pembentukan Kepribadian Muslim pada Anak Usia Sekolah 7-12 Tahun. Skripsi, Fakutas Tabiyah UN Sunan Kalijaga Yogyakarta.

Rustaman, N.Y. (2005). Strategi Belajar Mengajar Biologi. Malang: Universitas Negeri Malang.

Saptorini. (2008). Peningkatan Keterampilan Generik Sains Bagi Mahasiswa Melalui Perkuliahan Praktikum Kimia Analisis Instrumen Berbasis Inkuiri. Dalam Febriana, A., Ibrohim, \& Mahanal, S. (2016). Potensi Pembelajaran Inkuiri dalam Menumbuhkan Sikap Siswa Terhadap Lingkungan. Prosiding Seminar Nasional Pendidikan IPA Pascasarjana UM, Vol 1.

Septiani, D. (2013). Efektivitas Model Inquiry Based Learning (IBL) Berbantuan Modul dalam Meningkatkan Pemahaman Konsep dan Ketermapilan Generik Sains Siswa. Skripsi, Fakultas Matematika dan Ilmu Pengetahuan Alam Universitas Negeri Semarang.

Slameto. (2003). Belajar dan Faktor-Faktor yang Mempengaruhinya. Jakarta: Rhineka Cipta.

Sudarmin. (2007). Pengembangan Model Pembelajaran Kimia Organik dan Keterampilan Generik Sains (MPKOKG) bagi Calon Guru Kimia. Dalam Septiani, 
D. (2013). Efektivitas Model Inquiry Based Learning (IBL) Berbantuan Modul dalam Meningkatkan Pemahaman Konsep dan Ketermapilan Generik Sains Siswa. Skripsi, Fakultas Matematika dan Ilmu Pengetahuan Alam Universitas Negeri Semarang.

Sugiyono. (2010). Metode Penelitian Pendidikan, Bandung: Alfabeta.

Suriyani. (2010). Pengaruh Model Pembelajaran Inkuiri Terhadap Keterampilan Generik Sains dan Hasil Belajar Siswa Kelas X SMA Negeri 1 Tinombo. Dalam Darmawan, J., Halim, A., \& Nur, A. (2013). Metode Pembelajaran Eksperimen Berbasis Inkuiri untuk Meningkatkan Pemahaman Konsep dan Keterampilan Generik Sains Siswa SMA. Jurnal Pendidikan Sains Indonesia (JPSI).

Trihastuti, S. (2008). Pembelajaran Keterampilan Proses, Inquiry dan Discovery Learning. Diakses tanggal 25 November $2017 \quad$ dari http://umifatmawati.blog.uns.ac.id/

Veloo, A., Selvan P., \& R Vikneswary. (2013). Inquiry Based Instruction, Students' Attitudes and Teachers' Support Towards Science Achievement in Rural Primary Schools. Procedia Social and Behavioral Sciences. Vol. 93, 65-69.

Yuliani, H., Widha, S., \& Suparmi. (2012). Pembelajaran Fisika dengan Pendekatan
Keterampilan Proses dengan Metode Eksperimen dan Demonstrasi ditinjau dari Sikap Ilmiah dan Kemampuan Analisis. Dalam Putra, N.A.R., Abdurrahman., \& Suana, W. (2010). Pengaruh Keterampilan Proses Sains dan Sikap Ilmiah Terhadap Pemahaman Konsep IPA. Diakses tanggal 30 Agustus 2017 dari http://jurnal.fkip.unila.ac.id/index.php/JP F/article/viewFile/8861/5560

Yuniarita, F. (2014). Penerapan Pembelajaran Inkuiri Terbimbing untuk Meningkatkan Keterampilan Generik Sains Siswa SMP. Jurnal Pengajaran MIPA, Vol. 19 (1), 111-116. 
Jurnal Pendidikan Sains (JPS) Vol 06 No.01 (2018) 24-33 